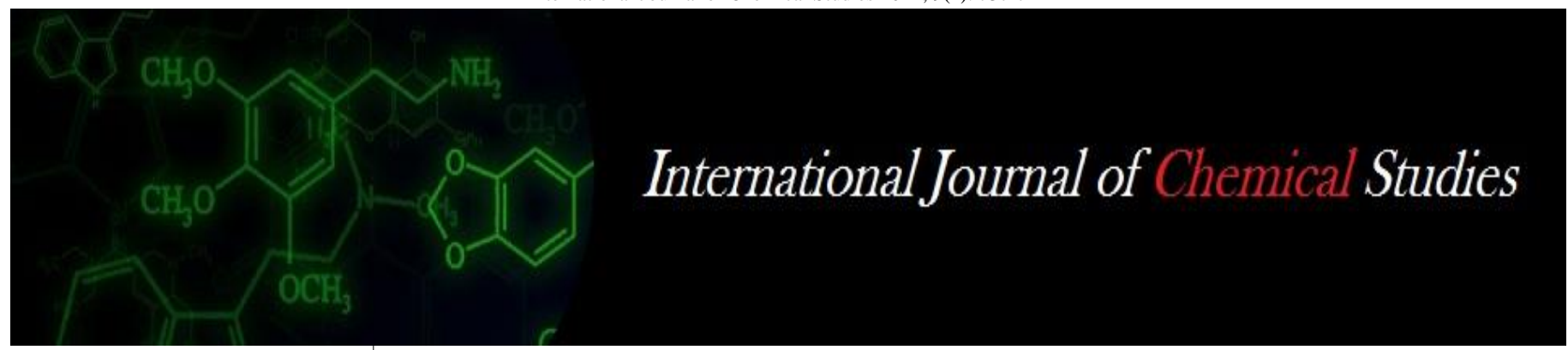

P-ISSN: 2349-8528

E-ISSN: 2321-4902

www.chemijournal.com

IJCS 2021; 9(2): 737-741

(C) 2021 IJCS

Received: 14-01-2021

Accepted: 18-02-2021

\section{DR Gamit}

Department of Genetics and

Plant Breeding, Navsari

Agricultural University, Navsari,

Gujarat, India

\section{CG Intwala}

Main Sugarcane Research

Station, Navsari Agricultural

University, Navsari, Gujarat,

India

V Lodam

Pulses Research Station, Navsari Agricultural University, Navsari, Gujarat, India
Corresponding Author: DR Gamit

Department of Genetics and Plant Breeding, Navsari

Agricultural University, Navsari, Gujarat, India

\section{Correlations and path analysis studies on yield and its components in $F_{2}$ generation of vegetable Indian bean (Lablab purpureus L.) sweet}

\author{
DR Gamit, CG Intwala and V Lodam
}

DOI: https://doi.org/10.22271/chemi.2021.v9.i2k.11975

\begin{abstract}
The present research work was carried out at Navsari Agricultural University, Navsari during the rabi2017 to study correlations among quantitative traits and their direct and indirect effect on pod yield per plant in $\mathrm{F}_{2}$ populations (N1-05-19 x N1-13-465, N1-13-465 x N1-08-203 and N1-05-19 x N1-08-225) of Indian bean. Correlation analysis revealed that, pod yield per plant showed positive and significant correlation with plant height at first picking, branches per plant at first picking, pods per plant, pods per cluster and average pod weight in all the three crosses. This indicated the simultaneous improvement of these characters by selection is possible. Path coefficient analysis revealed that plant height at first picking, pods per plant, average pod weight and fibre content had direct positive effects on pod yield per plant for all the crosses. This indicated that these characters played an important role in expressing high pod yield. Pod length exhibited direct positive effects on pod yield in crosses NI-05-19×NI-13-465 and NI-05-19×NI-08-225 while, shelling ratio and protein content depicted positive direct effect on pod yield

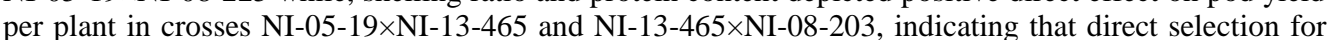
these characters may bring about an overall improvement in the pod yield of Indian bean.
\end{abstract}

Keywords: Correlation, path analysis, Indian bean

\section{Introduction}

Indian bean (Lablab purpureus L.) $(2 \mathrm{n}=22)$, is one of the most important indigenous legume vegetable crop grown in India. It is also known as lablab bean, field bean, egyptian bean, kidney bean, labia bean, dolichos bean, bonevist bean, seim bean, country bean, poor man's bean and waby bean. It is a multi-purpose crop grown for vegetable, pulse and forage throughout the country. Indian bean is predominantly a self-pollinated crop. It can fix atmospheric nitrogen to the extent of $170 \mathrm{~kg} / \mathrm{ha}$. The tender green pods and leaves are used for vegetable as they are the rich sources of protein (3.8\% in green pods). The pods are naturally rich in carbohydrates, proteins, fat and fibres, as well as minerals which include $\mathrm{Ca}, \mathrm{P}$ and $\mathrm{Fe}$ (Naeem et al. 2009) ${ }^{[10]}$. The protein content in pods and seeds ranges from 10-19\% and 15$25 \%$ respectively. The dry seeds are primarily consumed as split pulse and also used for various vegetable preparations such as 'tofu' or 'tempeh'. Dried seeds are usually boiled in water before eating as they contain toxic cyanogenic glucosides which is a source of hydrocyanic acid. In India, two types of Indian bean are recognised, Dolichos lablab var. typicus which is commonly known as "lablab bean", "papadi", "valor", "ballar". Another, Dolichos lablab var. lignosus which is commonly used known as "field bean" and "val". Both these types are under cultivation in India. Typicus is a garden type and is cultivated for its soft and edible pods. Lignosus is mainly cultivated for dry seed as pulse.

Selection for a specific character is known to result in correlated response for certain characters. Generally, plant breeders make selection for one or two attributes at a time, then it becomes important to know the effect of selection on other characters. Improvement on seed or pod yield, the most important target in many crops can be achieved by indirect selection through other easily observable and component characters. The association between seed or pod yield and a component character may sometimes be misleading due to an over-estimation or under estimation for its association with other characters. Thus, yield components have ultimate influence on yield, both directly and indirectly. Path analysis is carried out based on assumptions of linearity and additivity. 
Splitting of total correlation into direct and indirect effects, therefore, would provide a more meaningful interpretation of such association. Path coefficient, which is a standard partial regression coefficient, specifies the cause and effect relationship and measures the relative importance of each variable (Wright, 1921) ${ }^{[16]}$. Therefore, correlation in combination with path coefficient analysis is an important tool to find out the association and quantify the direct and indirect influence of one character upon another (Dewey and Lu, 1959) ${ }^{[4]}$.

\section{Material and Methods}

The experimental material for present evaluation comprised of segregating generations of three crosses involving four diverse parents viz., NI-05-19, NI-13-465, NI-08-203, NI-08225 and three $F_{1}$ and $F_{2}$ generations derived from three crosses viz., NI-05-19×NI-13-465, NI-13-465×NI-08-203 and NI-05-19 $\times$ NI-08-225. The $\mathrm{F}_{1} \mathrm{~s}$ were grown during the rabi2016 and $F_{2}$ generations were derived through selfing of $F_{1}$ generations. Evaluation of three $\mathrm{F}_{2}$ generations along with the parents and $F_{1}$ generations was carried out in non-replicated trial during rabi-2017.Each row consisted of 20 plants with spacing of $90 \times 45 \mathrm{~cm}^{2}$ inter and intra row spacing. Each $\mathrm{F}_{2}$ generation was raised with minimum of 240 plant population during rabi-2017 along with $\mathrm{F}_{1} \mathrm{~s}$ and parents and individual plant observations were recorded from 200 randomly selected plants. While, each parent and $\mathrm{F}_{1}$ consisted of 40 plants and observations were recorded from 20 randomly selected plants. Observations on twelve different quantitative and qualitative characters viz., days of first flowering, plant height at first picking, branches per plant at first picking, pods per plant, pods per cluster, pod length, number of seeds per pod, pod yield per plant, average pod weight, shelling ratio, protein content and fibre content were recorded from parents, $F_{1}$ s and derived $\mathrm{F}_{2}$ generations. Data recorded for all the characters were subjected to statistical analysis.

\section{Results and Discussion \\ Correlation analysis}

Positive and significant correlation of pod yield per plant with the characters plant height at first picking, branches per plant at first picking, pods per plant, pods per cluster and average pod weight was observed in all F2 generations, while pod length and number of seeds per pod also exhibited positive and significant correlation pod yield per plant in NI-05-19 $\mathrm{x}$ NI-13-465 (Table 1A, 2A, and 3A). These results were in close agreement with earlier workers viz., Mishra et al. (2008) [8, 9], Katiyar and Dixit (2009) [7], Rai et al. (2009) [12], Upadyay and Mehta (2010) [14], Angadi et al. (2012) [1], Hanumantrao et al. (2016) ${ }^{[6]}$ and Singh et al. (2018) ${ }^{[13]}$.

Branches per plant at first picking exhibited positive and significant correlation with the traits viz., pods per plant, pods per cluster, pod yield per plant and average pod weight in all segregating generations under study. The results are in accordance with the reports of Venkatesan et al. (2003) ${ }^{[15]}$, Konda et al. (2008) ${ }^{[8]}$ and Hanumantrao et al. (2016) [6]. Among all crosses, pods per plant depicted positive and significant correlation with characters like pods per cluster, pod yield per plant in all three segregating crosses. It also exhibited positive and significant correlation with average pod weight in the crosses NI-05-19×NI-13-465 and NI-0519xNI-08-225. Similar results reported by Bangar et al. (2008), Mishra et al. (2008) [8, 9], Konda et al. (2008) ${ }^{[8],}$ Katiyar and Dixit (2009) ${ }^{[7]}$. Plant height showed negative and significant correlation with days of first flowering in the F2 generations of NI-13-465×NI-08-203. While, positive and significant association observed with branches per plant at first picking, pods per plant, pods per cluster, pod yield per plant and average pod weigh in the all segregating populations. Positive and significant correlation observed with shelling ratio $(0.148 *)$ in the cross NI-13-465×NI-08203. The results are in accordance with the findings of Golani et al. (2007) ${ }^{[5]}$ and Konda et al. (2008) ${ }^{[8]}$, Angadi et al. (2012) ${ }^{[1]}$, Hanumantrao et al. (2016) ${ }^{[6]}$ and Singh et al. (2018) ${ }^{[13]}$. Positive and significant correlation of pods per plant with pods per cluster and pod yield per plant was observed in all $\mathrm{F}_{2}$ crosses. Pods per plant depicted positive and significant correlation with average pod weight in the cross NI-05-19×NI-13-465 and NI-05-19×NI-08-225. Similar results were reported by Hanumantrao et al. (2016) ${ }^{[6]}$ and Singh et al. (2018) ${ }^{[13]}$. Pod length showed positive and significant correlation with number of seeds per pod in all F2 generations. It was positively and significantly correlated with pod yield per plant in F2 generations cross NI-05-19×NI-13465 and NI-05-19 $\times$ NI-08-225. While, in crosses NI-05$19 \times$ NI-13-465 and NI-05-19×NI-08-225, it had positive and significant correlation with average pod weight. Similar results were obtained by Angadi et al. (2012) ${ }^{[1]}$. Average pod weight showed positive and significant correlation with shelling ratio in the F2 crosses NI-13-465×NI-08-203 and NI05-19×NI-08-225 except NI-05-19×NI-13-465. Similar results were reported by Angadi et al. (2012) ${ }^{[1]}$, Hanumantrao et al. (2016) ${ }^{[6]}$, and Singh et al. (2018) ${ }^{[13]}$. Generally, the character like plant height at first picking, branches per plant, pods per plant, pods per cluster and average pod weight was observed in all F2 generations, exhibited positive and significant correlation with pod yield per plant would permissible for selecting as yield component trait for improvement of pod yield in segregating populations.

\section{Path coefficient analysis}

Path coefficient analysis accommodates assistance for categorizing the total correlation in to direct and indirect effects. The results of path analysis are shown in Table 2A, 2B and 2C. Path analysis involving three segregating populations revealed that traits like plant height at first picking, pods per plant, branches per plant at first picking, pod length, average pod weight, shelling ratio, protein content and fibre content had positive direct effect on pod yield per plant in the F2 segregating population of NI-05-19 $\times$ NI-13465 , while plant height at first picking, pods per plant, number of pods per plant, average pod weight, shelling ratio, protein content and fibre content exhibit positive direct effect on pod yield per plant in NI-13-465 $\times$ NI-08-203. The F2 of cross NI-05-19×NI-08-225 rendered positive direct effect of traits like days of first flowering, plant height at first picking, pods per plant, pod length, average pod weight and fibre content on pod yield per plant. The results are in accordance with the findings of Konda et al. (2008) ${ }^{[8]}$, Mishra et al. (2008) ${ }^{[8,9]}$, Rai et al. (2009) ${ }^{[12]}$, Chattopadyay and Dutta (2010) [3], Upadhyay and Mehta (2010) ${ }^{[14]}$, Hanumantrao et al. (2016) ${ }^{[6]}$ and Singh et al. (2018) ${ }^{[13]}$.

The traits, days of first flowering, pods per cluster, number of seeds per pod showed negative direct effect on pod yield per plant in F2 cross NI-05-19 $\times$ NI-13-465, while in the cross NI13-465×NI-08-203, days of first flowering, branches per plant at first picking, pods per cluster, pod length depicted negative direct effect on pod yield per plant. The cross NI-05-19×NI08-225 rendered negative direct effect of the traits, branches per plant at first picking, pods per cluster, number of seeds 
per pod, shelling ratio and protein content on pod yield per plant. Similar results were observed by Rai et al. (2008) ${ }^{[11]}$, Chattopadhyay and Dutta (2010) [3], Hanumantrao et al. (2016) ${ }^{[6]}$ and Singh et al. (2018) ${ }^{[13]}$.

The path analysis revealed that plant height at first picking, pods per plant, average pod weight and fibre content had direct positive effects on pod yield. This indicated that these characters played an important role in expressing high pod yield. Therefore, direct selection for these characters may about bring an overall improvement in the pod yield. Considering all the aspects together it is apparent from path analysis that maximum effects as well as appreciable indirect influences were exerted by branches per plant, pods per cluster and pod length. This characters also exhibited significant and positive association with pod yield per plant. Hence, they may be considered as the most important yield contributing characters and appropriate prominence should be placed as these components while breeding for high yielding in Indian bean.

\section{Conclusion}

Based on correlation and path analysis, it could be concluded that in breeding programme aiming to improve pod yield per plant in Indian bean, more weightage should be given on pods per plant, average pod weight and plant height at first picking as they are the most important component traits. Hence, these traits should be considered as selection criteria for pod yield improvement in vegetable Indian bean.

Table 1A: Phenotypic correlation coefficients of pod yield per plant with other characters in $\mathrm{F}_{2}$ generation of NI-05-19 $\times$ NI-13-465 in Indian bean

\begin{tabular}{|c|c|c|c|c|c|c|c|c|c|c|c|c|}
\hline Characters & DFF & $\mathbf{P H}$ & BPP & PPP & PPC & PL & NSPP & PYPP & APW & SR & $\mathbf{P C}$ & FC \\
\hline DFF & 1.000 & & & & & & & & & & & \\
\hline $\mathrm{PH}$ & -0.091 & 1.000 & & & & & & & & & & \\
\hline BPP & -0.101 & $0.301 * *$ & 1.000 & & & & & & & & & \\
\hline PPP & $-0.162 *$ & $0.585^{* *}$ & $0.604 * *$ & 1.000 & & & & & & & & \\
\hline PPC & -0.005 & $0.174 *$ & $0.233 * *$ & $0.348 * *$ & 1.000 & & & & & & & \\
\hline $\mathrm{PL}$ & 0.023 & 0.095 & 0.076 & 0.130 & 0.101 & 1.000 & & & & & & \\
\hline NSPP & 0.076 & -0.022 & 0.134 & 0.047 & 0.049 & $0.710 * *$ & 1.000 & & & & & \\
\hline PYPP & $-0.201 * *$ & $0.579 * *$ & $0.593 * *$ & $0.886 * *$ & $0.264 * *$ & $0.179 *$ & 0.090 & 1.000 & & & & \\
\hline APW & -0.123 & $0.269 * *$ & $0.246 * *$ & $0.304 * *$ & 0.005 & $0.173 *$ & $0.141^{*}$ & $0.623 * *$ & 1.000 & & & \\
\hline SR & 0.071 & 0.027 & -0.045 & -0.020 & 0.011 & 0.070 & 0.038 & 0.052 & 0.046 & 1.000 & & \\
\hline $\mathrm{PC}$ & 0.050 & 0.069 & 0.091 & 0.042 & 0.006 & -0.025 & 0.105 & 0.031 & -0.016 & -0.099 & 1.000 & \\
\hline FC & -0.061 & -0.069 & -0.108 & $-0.140 *$ & 0.004 & -0.121 & -0.020 & -0.112 & -0.021 & 0.012 & 0.046 & 1.000 \\
\hline $\begin{array}{l}\text { DFF - Days of } \\
\text { PH - Plant heig } \\
\text { BPP - Branche }\end{array}$ & $\begin{array}{l}\text { t flowerin } \\
(\mathrm{cm}) \text { at firs } \\
\text { er plant at }\end{array}$ & $\begin{array}{l}\text { picking } \\
\text { st picking }\end{array}$ & $\begin{array}{l}\text { PPP - Po } \\
\text { PPC - Po } \\
\text { PL- Pod }\end{array}$ & $\begin{array}{l}\text { per plant } \\
\text { s per clust } \\
\text { ngth }(\mathrm{cm})\end{array}$ & & $\begin{array}{l}\text { NSPP - Nu } \\
\text { PYPP - Po } \\
\text { APW - Av }\end{array}$ & $\begin{array}{l}\text { yield pe } \\
\text { aage pod }\end{array}$ & $\begin{array}{l}\text { ds per poc } \\
\text { plant }(\mathrm{g}) \\
\text { eight }(\mathrm{g})\end{array}$ & & $\begin{array}{l}\text { - Shellin } \\
\text { - Protein } \\
\text { - Fibre c }\end{array}$ & $\begin{array}{l}(\%), \\
\text { content } \\
\text { ontent }(c\end{array}$ & (\%) \\
\hline
\end{tabular}

Note: $*$ and $* *$, significant at $5 \%$ and $1 \%$ level of probability, respectively.

Table 1B: Phenotypic correlation coefficients of pod yield per plant with other characters in $\mathrm{F}_{2}$ generation of NI-13-465 $\times$ NI-08-203 in Indian bean

\begin{tabular}{|c|c|c|c|c|c|c|c|c|c|c|c|c|}
\hline Characters & DFF & PH & BPP & PPP & PPC & PL & NSPP & PYPP & APW & SR & PC & FC \\
\hline DFF & 1.000 & & & & & & & & & & & \\
\hline $\mathrm{PH}$ & $-0.198 * *$ & 1.000 & & & & & & & & & & \\
\hline BPP & -0.102 & $0.255^{* * *}$ & 1.000 & & & & & & & & & \\
\hline PPP & -0.067 & $0.370 * *$ & $0.637 * *$ & 1.000 & & & & & & & & \\
\hline PPC & 0.002 & $0.203 * *$ & $0.382 * *$ & $0.466 * *$ & 1.000 & & & & & & & \\
\hline $\mathrm{PL}$ & -0.098 & $0.179 *$ & -0.102 & 0.004 & -0.018 & 1.000 & & & & & & \\
\hline NSPP & -0.038 & 0.026 & -0.052 & -0.038 & -0.062 & $0.540 * *$ & 1.000 & & & & & \\
\hline PYPP & -0.096 & $0.414 * *$ & $0.639 * *$ & $0.942 * *$ & $0.461 * *$ & 0.057 & -0.010 & 1.000 & & & & \\
\hline APW & -0.060 & 0.210 ** & $0.215^{* *}$ & 0.104 & $0.181^{*}$ & $0.153^{*}$ & 0.020 & $0.405^{* *}$ & 1.000 & & & \\
\hline SR & -0.001 & $0.148 *$ & -0.058 & 0.005 & -0.044 & $0.230 * *$ & 0.065 & $0.140^{*}$ & $0.375 * *$ & 1.000 & & \\
\hline $\mathrm{PC}$ & 0.053 & 0.131 & -0.043 & 0.042 & 0.058 & 0.003 & -0.070 & 0.047 & 0.024 & 0.091 & 1.000 & \\
\hline $\mathrm{FC}$ & -0.030 & -0.099 & -0.017 & -0.069 & 0.003 & -0.039 & -0.059 & -0.073 & -0.032 & -0.044 & -0.060 & 1.000 \\
\hline
\end{tabular}

DFF - Days of first flowering, PPP - Pods per plant, NSPP - Number of seeds per pod, SR- Shelling (\%), PH - Plant height (cm) at first picking, PPC - Pods per cluster, PYPP - Pod yield per plant (g), PC - Protein content (\%), BPP - Branches per plant at first picking, PL - Pod length (cm), APW - Average pod weight (g), FC - Fibre content $(\%)$

Note: $*$ and $* *$, significant at $5 \%$ and $1 \%$ level of probability, respectively.

Table 1C: Phenotypic correlation coefficients of pod yield per plant with other characters in $\mathrm{F}_{2}$ generation of NI-05-19 $\times$ NI-08-225 in Indian bean

\begin{tabular}{|c|c|c|c|c|c|c|c|c|c|c|c|c|}
\hline Characters & DFF & PH & BPP & PPP & PPC & PL & NSPP & PYPP & APW & SR & PC & FC \\
\hline DFF & 1.000 & & & & & & & & & & & \\
\hline $\mathrm{PH}$ & 0.042 & 1.000 & & & & & & & & & & \\
\hline BPP & 0.069 & $0.443 * *$ & 1.000 & & & & & & & & & \\
\hline PPP & -0.010 & $0.518 * *$ & $0.381 * *$ & 1.000 & & & & & & & & \\
\hline PPC & 0.003 & $0.236 * *$ & $0.245 * *$ & $0.320 * *$ & 1.000 & & & & & & & \\
\hline PL & 0.006 & $0.231 * *$ & 0.085 & 0.134 & 0.024 & 1.000 & & & & & & \\
\hline
\end{tabular}




\begin{tabular}{|c|c|c|c|c|c|c|c|c|c|c|c|c|}
\hline NSPP & -0.040 & 0.138 & -0.022 & 0.003 & -0.068 & $0.794 * *$ & 1.000 & & & & & \\
\hline PYPP & 0.010 & $0.526 * *$ & $0.374 * *$ & $0.917 * *$ & $0.307 * *$ & $0.182 * *$ & 0.041 & 1.000 & & & & \\
\hline APW & 0.047 & $0.311 * *$ & $0.257 * *$ & $0.230 * *$ & $0.244 * *$ & 0.090 & 0.065 & $0.456 * *$ & 1.000 & & & \\
\hline SR & -0.065 & 0.041 & 0.116 & 0.055 & 0.100 & $0.156^{*}$ & 0.093 & 0.101 & $0.199 * *$ & 1.000 & & \\
\hline $\mathrm{PC}$ & -0.035 & -0.048 & -0.058 & 0.066 & 0.041 & -0.012 & -0.082 & 0.038 & -0.074 & -0.069 & 1.000 & \\
\hline FC & -0.093 & 0.025 & 0.025 & 0.089 & 0.063 & -0.050 & -0.088 & 0.082 & -0.012 & -0.093 & -0.041 & 1.000 \\
\hline
\end{tabular}

DFF - Days of first flowering, PPP - Pods per plant, NSPP - Number of seeds per pod, SR - Shelling (\%), PH - Plant height (cm) at first picking, PPC - Pods per cluster, PYPP - Pod yield per plant, PC - Protein content (\%), BPP - Branches per plant at first picking, PL - Pod length (cm), APW - Average pod weight (g), FC - Fibre content (\%)

Note: $*$ and $* *$, significant at $5 \%$ and $1 \%$ level of probability, respectively.

Table 2A: Path coefficient analysis of component characters towards pod yield per plant in $\mathrm{F}_{2}$ generation of NI-05-19 $\times$ NI-13-465 in Indian bean

\begin{tabular}{|c|c|c|c|c|c|c|c|c|c|c|c|c|}
\hline ers & DFF & PH & BPP & PPP & PPC & PL & NSPP & APW & SR & PC & FC & PCPY(r) \\
\hline DFF & 03385 & 00351 & 00643 & 11444 & 0005 & 00068 & 00183 & .04606 & 00379 & .00045 & 0.00033 & \\
\hline $\mathrm{H}$ & & & & & & & & & & & & \\
\hline BPF & 02341 & & & & & & & & & & -0.00060 & \\
\hline & 00547 & 60 & 50 & & & & & & & & & \\
\hline C & 8 & 0.00 & & 0.2 & .0 & & & & 58 & 06 & 02 & $4 * *$ \\
\hline & & & & & & & & & & & 67 & \\
\hline$\overline{\mathrm{PP}}$ & 56 & 34 & & & -0 . & 00 & & & & 096 & 002 & \\
\hline APW & 0.00417 & & & & -0.00004 & & -0.0 & & 244 & -0.00015 & -0.00011 & $0623 * *$ \\
\hline-7 & .00240 & 0.00104 & -0.00286 & \begin{tabular}{|l|}
-0.01398 \\
\end{tabular} & -0.00009 & 0.00207 & -0.00093 & 0.01704 & 0.05344 & -0.00090 & 0.00007 & 0.052 \\
\hline & & & & & & & & & -0.0 & & & \\
\hline- & 0.00205 & -0.00266 & -0.00689 & -0.09933 & -0.00003 & 0.00358 & 0.00001 & -0.00773 & 0.00064 & 0.00042 & 0.00052 & -0.112 \\
\hline
\end{tabular}

DFF - Days of first flowering, PPP - Pods per plant, NSPP - Number of seeds per pod, SR - Shelling (\%), PH - Plant height (cm) at first picking, PPC - Pods per cluster, PYPP- Pod yield per plant (g), PC - Protein content (\%), BPP - Branches per plant at first picking, PL - Pod length (cm), APW- Average pod weight(g), FC - Fibre content (\%), PCPY - Phenotypic correlation with pod yield, Residual $=0.07040$

Note: $*$ and $* *$, significant at $5 \%$ and $1 \%$ level of probability, respectively.

Direct and indirect effect of different traits on pod yield per plant in Indian bean indicated by bold diagonal and off diagonal characters, respectively.

Table 2B: Path coefficient analysis of component characters towards pod yield per plant in F2 generation of NI-13-465 $\times$ NI-08-203 in Indian bean

\begin{tabular}{|c|c|c|c|c|c|c|c|c|c|c|c|c|}
\hline haracters & DFF & PH & BPP & PPP & PPC & PL & NSPP & APW & SR & PC & FC & PCPY(r) \\
\hline DFF & 0.01527 & .00228 & .00104 & 0.06175 & 0.00004 & 00155 & & & & & & -0.096 \\
\hline 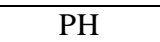 & & & & & & & & & & & & \\
\hline & & & & & & & & & & & & \\
\hline PPP & & 00425 & -0.0 & 092 & -0.00934 & 0.00006 & & & & & & $42 * *$ \\
\hline PPC & 03 & 00233 & & 0.42919 & & & & & & & & \\
\hline & & 6 & & .0( & 0.00036 & & & & & & & \\
\hline & & & & & & & & & & & & \\
\hline $\mathrm{W}$ & 2 & 41 & 9 & 4 & 64 & 41 & & & & 0.0 & -0.0 & $0.405^{* *}$ \\
\hline SR & & & & 0.00 & & & & & & 0.00009 & -0.0 & $0.140 *$ \\
\hline $\mathrm{PC}$ & -0.00080 & .00151 & 0.00044 & 0.03895 & -0.00116 & -0.00005 & -0.0 & 0.0 & & 0.00095 & -0.00019 & 0.047 \\
\hline FC & 0.00046 & -0.00113 & 0.00018 & -0.06384 & -0.00005 & 0.00062 & -0.00139 & -0.00996 & -0.00083 & -0.00006 & 0.00318 & -0.073 \\
\hline
\end{tabular}

DFF - Days of first flowering, PPP - Pods per plant, NSPP - Number of seeds per pod, SR - Shelling (\%), PH - Plant height (cm) at first picking, PPC - Pods per cluster, PYPP- Pod yield per plant (g), PC - Protein content (\%), BPP - Branches per plant at first picking, PL - Pod length (cm), APW - Average pod weight (g), FC - Fibre content (\%), PCPY- Phenotypic correlation with pod yield, Residual = 0.01624

Note: $*$ and $* *$, significant at $5 \%$ and $1 \%$ level of probability, respectively.

Direct and indirect effect of different traits on pod yield per plant in Indian bean indicated by bold diagonal and off diagonal characters, respectively.

Table 2C: Path coefficient analysis of component characters towards pod yield per plant in F2 generation of NI-05-19 $\times$ NI-08-225 in Indian bean

\begin{tabular}{|c|c|c|c|c|c|c|c|c|c|c|c|c|}
\hline Characters & DFF & PH & BPP & PPP & PPC & PL & NSPP & APW & SR & $\mathbf{P C}$ & FC & PCPY(r) \\
\hline DFF & 0.00595 & .00006 & -0.00169 & -0.00820 & -0.00010 & 0.00048 & 0.00191 & 0.01249 & 0.00009 & 0.00005 & -0.00098 & 0.010 \\
\hline $\mathrm{PH}$ & 0.00025 & 0.00138 & -0.01079 & 0.44745 & -0.00829 & 0.01944 & -0.00661 & 8318 & -0.00005 & 0.00008 & 0.00026 & $0.526^{* *}$ \\
\hline BPP & 0.00041 & 0.00061 & -0.02437 & 0.32874 & -0.00860 & 0.00717 & 0.00104 & 0.06863 & -0.00015 & 0.00009 & 0.00026 & $0.374 * *$ \\
\hline PPP & -0.00006 & 0.00071 & -0.00928 & 0.86332 & -0.01125 & 0.01126 & -0.00016 & 0.06142 & -0.00007 & -0.00010 & 0.00094 & $0.917 * *$ \\
\hline PPC & 0.00002 & 0.00033 & -0.00597 & 0.27658 & -0.03510 & 0.00198 & 0.00324 & 0.06522 & -0.00013 & -0.00006 & 0.00066 & $0.307 * *$ \\
\hline PL & 0.00003 & 0.00032 & -0.00208 & 0.11568 & -0.00083 & 0.08400 & & 399 & -0.00020 & 0.00002 & -0.00053 & $0.182 * *$ \\
\hline NSPP & -0.00024 & 0.00019 & 0.00053 & 0.00287 & 0.00237 & 0.06672 & -0.0 & 725 & -0.00012 & 0.00013 & -0.00093 & 0.041 \\
\hline APW & 0.00028 & 0.00043 & -0.00626 & 0.19855 & -0.00857 & 0.00754 & -0.0 & 0.26708 & -0.00026 & 0.00012 & -0.00012 & $0.456 * *$ \\
\hline SR & -0.00039 & 0.00006 & -0.00283 & 0.04772 & -0.00351 & 0.01312 & -0.00445 & 0.05305 & -0.00131 & 0.00011 & -0.00098 & 0.101 \\
\hline
\end{tabular}




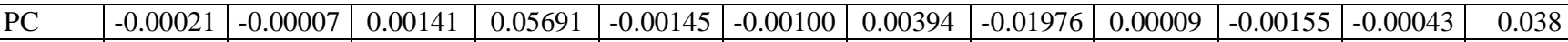

\begin{tabular}{|l|l|l|l|l|l|l|l|l|l|l|l|l|l|} 
FC & -0.00055 & 0.00003 & -0.00061 & 0.07726 & -0.00220 & -0.00423 & 0.00424 & -0.00312 & 0.00012 & 0.00006 & 0.01054 & 0.082 \\
\hline
\end{tabular}

DFF - Days of first flowering, PPP - Pods per plant, NSPP - Number of seeds per pod, SR - Shelling (\%), PH - Plant height (cm) at first picking, PPC - Pods per cluster, PYPP - Pod yield per plant (g), PC - Protein content (\%), BPP - Branches per plant at first picking, PL - Pod length (cm), APW - Average pod weight (g), FC - Fibre content (\%), PCPY - Phenotypic correlation with pod yield, Residual $=0.09193$

Note: * and **, significant at 5\% and $1 \%$ level of probability, respectively.

Direct and indirect effect of different traits on pod yield per plant in Indian bean indicated by bold diagonal and off diagonal characters, respectively.

\section{References}

1. Angadi P, Patil MG, Angadi A. Correlation studies in french bean (Phaseolus vulgaris L.). The Asian Journal of Horticulture 2012;2(7):574-578.

2. Bangar ND, Lakra A, Chavan BH. Correlation and path coefficient of analysis in moth bean. Journal of Maharashtra Agricultural Universities 2008;33(2):164166.

3. Chattopadyay A, Dutta S. Characterization and identification of selection indices of pole type dolichos bean. Vegetable crops research bulletin 2010;73(1):3345.

4. Deway DR, Lu KH. A correlation and path coefficient analysis of components of crested wheat grass seed production. Agron. J 1959;51(1):515-518.

5. Golani IJ, Mehta DR, Naliyadhra MV, Patel RK. Genetic variability, correlation and path analysis for green pod yield and its characters in hyacinth bean. The Orissa Journal of Horticulture 2007;35(1):71-75.

6. Hanumantrao VH. Study on variability, heritability, genetic advance and correlation in bush type Indian bean. M.Sc (Agri.) Thesis submitted to Krishi Vishwa Vidyalaya, Gwalior, India 2016.

7. Katiyar PK, Dixit GP. Multivariate analysis for genetic divergence in field pea (Pisum sativum) germplasms. Indian Journal of Agricultural Sciences 2009;79(3):181183.

8. Konda CR, Sailmath PM, Mishra MN. Correlation and path analysis in black gram (Vigna mungo (L.) Hepper). Legume Research 2008;31(3):202-205.

9. Mishra S, Kumar M, Sahu GS. Relationships among yield contributing characters in pole type french bean (Phaseolus vulgaris L.). The Orissa Journal of Horticulture 2008;36(2):108-113.

10. Naeem M, Masoor M, Khan A, Morris JB. Agrobotanical attributes, nitrogen-fixation, enzyme activities and nutraceuticals of hyacinth bean (Lablab purpureus L.) A bio-functional medicinal legume. American Journal of Plant Physiology 2009;4(1):58-62.

11. Rai N, Singh PK, Verma A, Lal H, Yadav DS, Rai M. Multivariate characterization of Indian bean (Lablab purpureus (L.) Sweet.) genotypes. Journal of Plant Genetic Resources 2008;21(1):42-45.

12. Rai N, Asati BS, Singh AK. Genetic divergence in Indian bean. Legume Research 2009;32(2):166-172.

13. Singh Parmod K, Rai N, Bhardwaj DR, Anand Prakash. Correlation, path and cluster analysis in hyacinth bean (Lablab purpureus L. sweet). Journal of agricultural Technology 2018;7(4):1117-1124.

14. Upadhyay D, Mehta N. Biometrical studies in dolichos bean (Dolichos lablab L.) for Chattisgarh Plains. Research Journal of Agricultural Sciences 2010;1(4):441447.

15. Venkatesan M, Prakash M, Ganesan J. Correlation and path analysis in cowpea (Vigna unguiculata L.). Legume Research 2003;26(2):105-108.
16. Wright S. Correlation and causation. J Agric Res 1921;20:557-587. 